32,0
81,1914

DP-869

AEC RESEARCH AND DEVELOPMENT REPORT

\title{
DESIGN OF CONDUCTIVITY CELLS \\ FOR STRONG ELECTROLYTES
}

R. C. PROPST

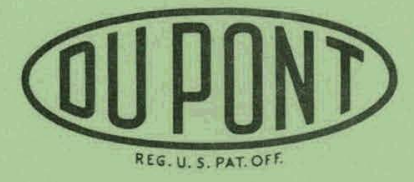

Savannah River Laboratory

Aiken, South Carolina 


\section{DISCLAIMER}

This report was prepared as an account of work sponsored by an agency of the United States Government. Neither the United States Government nor any agency Thereof, nor any of their employees, makes any warranty, express or implied, or assumes any legal liability or responsibility for the accuracy, completeness, or usefulness of any information, apparatus, product, or process disclosed, or represents that its use would not infringe privately owned rights. Reference herein to any specific commercial product, process, or service by trade name, trademark, manufacturer, or otherwise does not necessarily constitute or imply its endorsement, recommendation, or favoring by the United States Government or any agency thereof. The views and opinions of authors expressed herein do not necessarily state or reflect those of the United States Government or any agency thereof. 


\section{DISCLAIMER}

Portions of this document may be illegible in electronic image products. Images are produced from the best available original document. 
This report was prepared as an account of Government sponsored work. Neither the United States, nor the Commission, nor any person acting on behalf of the Commission:

A. Makes any warranty or representation, expressed or implied, with respect to the accuracy, completeness, or usefulness of the information contained in this report, or that the use of any information, apparatus, method, or process disclosed in this report may not infringe privately owned rights; or

B. Assumes any liabilities with respect to the use of, or for damages resulting from the use of any information, apparatus, method, or process disclused in this report.

As used in the abnve, "person acting on behalf of the Commission" includes any employee or contractor of the commission, or emplnyee of such contractor, to the extent that such employee or contractor of the Commission, or employee of such contractor prepares, disseminates, or provides access to, any information pursuant to his employment or contract with the Commission, or his employment with such contractor.

Printed in USA. Price $\$ 0.50$ Avallable from the Office of Technical Services

U. S. Department of Commerce Washington 25, D. C. 


\title{
DESIGN OF CONDUCTIVITY CELLS FOR STRONG ELECTROLYTES \\ by \\ Robert C. Propst \\ Approved by \\ H. M. Kelley, Research Manager \\ Analytical Chemistry Division \\ June 1964
}

\author{
E. I. DU PONT DE NEMOURS \& COMPANY \\ EXPLOSIVES DEPARTMENT - ATOMIC ENERGY DIVISION \\ TECHNICAL DIVISION - SAVANNAH RIVER LABORATORY \\ AIKEN, SOUTH CAROLINA \\ CONTRACT AT (07.2) - I WITH THE \\ UNITED STATES ATOMIC ENERGY COMMISSION
}




\begin{abstract}
Design and operating characteristics of conductivity cells were examined to improve the accuracy and precision of conductance data from highly conductive process solutions. The characteristics investigated included cell dimensions, size and nature of electrodes, and frequency and voltage ranges. Cell designs that confined the solution in a long column (where length $\gg$ diameter) minimlzed the importance of constant electrode area and virtually eliminated the effect of fouling of electrode surfaces by entralned organic solvents. Satisfactory operation with simulated dissolver solution from the Purex process was demonstrated with several cells constructed from new design criteria.
\end{abstract}




\section{CONTENTS}

$\therefore \quad \therefore \quad$ Page

List of Tables and Figures 4

Introduction 5

Summary $\therefore$ : 5

Discussion - . . 6

Equipment 9

Electrode Separation 11

Cross-Sectional Area of Solution 13

Electrode Area $\quad 15$

Frequency 16

Platinized Electrodes _. . 17

Amplitude of Cell Voltage 18

Electrode Materials 19

Water-Insoluble Organlc Solvents . . 21

Bridge and Constant Current Methods 22

Absolute Nature of the Electrode Separation Method 22

Application to the Uranyl Nitrate - N1tric Ac1d

System $\quad . \quad 23$

References $\quad 25$ 


\section{LIST OF TABLES AND FIGURES}

Table

Page

I Effect of Electrode Separation . . 12

II Effect of Electrode Area 13

III Effect of Cross-Sectional Area of Cell 14

IV Effect of Cell Cross Section 15

$\mathrm{V}$ Effect of Amplitude of Ce.1. Voltage.. 18

VI Effect of Organic Solvents on Cell Response 21

F1gure

1 Bridge Apparatus 8

2 Apparatus for Impedance Studies 9

3 Conductivity Cells : 10

4 AC Electrolysis Apparatus. 11

5 Effect of Electrode. Area at Zero Interelectrode Distance . 15

6 Effect of Platinized Electrodes. . 17

7 Cyclograms: of $0.14 \mathrm{M}$ UNH $-0.2 \mathrm{M} \cdot \mathrm{HNO}_{3} .20$

8 Specific Gravity vs Conductivity, $\mathrm{UO}_{2}\left(\mathrm{NO}_{3}\right)_{2}-\mathrm{HNO}_{3}$ Sy'stem 


\title{
DESIGN OF CONDUCTIVITY CELLS FOR STRONG ELECTROLYTES
}

\author{
INTRODUCTION
}

Close control of process variables is required to minimize process losses in the Purex process. Th1s control is maintained by laboratory analyses of samples that are withdrawn from process streams. Continuing effort is directed toward the use of in-line methods of analysis that utilize physical parameters as critical indices of the composition of multicomponent systems. In this sense the Purex dissolver solution is a two-component system (uranyl nitrate and nitric acid) requiring two critical indices. The concentration of these components may be determined by measurements of the electrical conductivity and specific gravity of the solution.

Some attempts to apply conductometric techniques to solutions of high conductivity have falled, elther because of anomalies observed with dip-type cells, or because the effective electrode area is reduced by dissolved and suspended solvent in lie piviess solution. Thue the sell must. he designed to minimize these factors.

No references were found concerning the design of conductivity cells to minimize the effects of changes in the effective electrode area, although a three-electrode cell( 1 ) has been proposed as a means for eliminating polarization effecti. While the three-electrode design is probably adequate for some installations, its performance can be improved if the changes in the effective electrode area can be minimized. This work was undertaken in an effort to define the parameters that determine the response of a conductivity cell and to design a cell with a response that would be a true measure of the absolute conductivity of the solution without calibration.

\section{SUMMARY}

Design criteria were determined for the construction and in-line operation of conductivity cells 1 is aqueous streams from the Purex process. In the new design concept, gross changes in electrode area due to adsorbed organic solvent have a minimum effect on the observed conductivity. The critical variable that minimizes the effect of electrode area was shown to be the dimensions of the column of solution between the electrodes.

The basic design phllosophy was demonstrated for a cell of new design by deliberately flooding the cell with organic solvent, thereby simulating a breakthrough of solvent into 
the aqueous stream. When the aqueous phase was flushed through the new cell, the conductivity readings returned promptly to normal with less than $1 \%$ error resulting from this drastic treatment. The effect of electrode area can be eliminated completely from the conductivity measurements by incorporating this principle into the design of a three-electrode cell(1) or by utilizing a technique based on electrode separation as established in this report. The latter technique provides a means for determining the absolute conductivity of solutions.

\section{DISCUSSION}

The orlginal criteria for obtalining reproducible measurements of electrical conductivity were proposed by Kohlrausch in 1875. In order to obtain the consistent results, Kohlrausch found it necessary to: (1.) design the cell so that the effective resistance was greater than 100 ohms, (2) incorporate large electrodes ( $1 \mathrm{~cm}^{2}$ or larger), (3) increase the frequency of the applied voltage to 1000 cycles per second, and (4) platinize the electrodes. The above criteria were established on an empirical basis(2). The success of the Kohlrausch method lies in platinization of the electrodes to minimize polarization effects that are in turn a function of the electrochemical processes which occur at the electrode. In an effort to make further 1mprovements, the above varlables were re-examined in the light of contemporary theories of faradalc admittance.

Contemporary theorles of the faradalc admittance of a polarized electrode $(3,4)$ are well established, and the AC Impedance of a polarized electrode can be represented by an equivalent circult that contains elements of pure resistance and capacitance $(3,5)$. Since a conductivity cell contains two electrodes, it is convenient to represent the $\mathrm{AC}$ impedance of the cell in terms of an electrical analog:

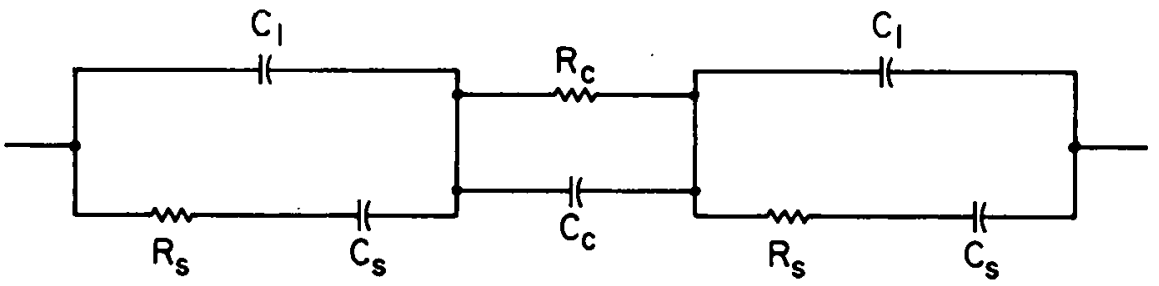


where $C_{1}=$ double layer capacity of the electrode-solution interface

$\mathrm{R}_{\mathrm{S}}=$ polarization resistance

$\mathrm{C}_{\mathrm{s}}=$ pseudocapac1tance due to polarization

$R_{c}=$ resistance of electrical path between electrodes

$\begin{aligned} C_{c}= & \text { capacitance between electrodes w1th the solvent } \\ & \text { as the dielectric }\end{aligned}$

However, the individual electrode impedances cannot be measured separately so that the circuit can be simplified as follows:

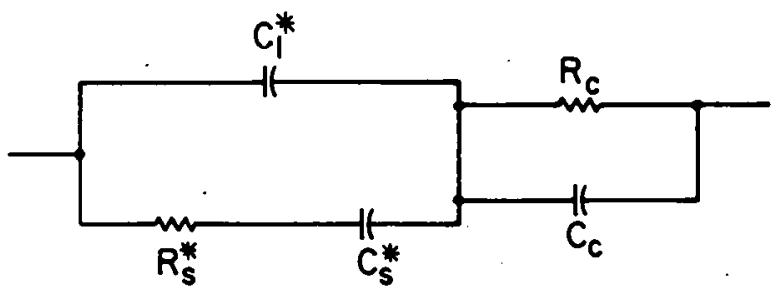

where $C_{1}^{*}, R_{S}^{*}$, and $C_{S}^{*}$ represent the combined impedances for both electrodes.

In the case of strong electrolytes where the frequency of measurement is 1 megacycle or less and the cell constant is less than unity, the circuit can be simplified still further, since the shunting effect of $C_{c}$ on $R_{c}$ will be negligible. The capacitance of a cell with a constant of unity and water as the dielectric is approximatel y 7 picofarads. Thus the capacitance $\mathrm{C}_{\mathrm{c}}$ can be eliminated, and the circult becomes

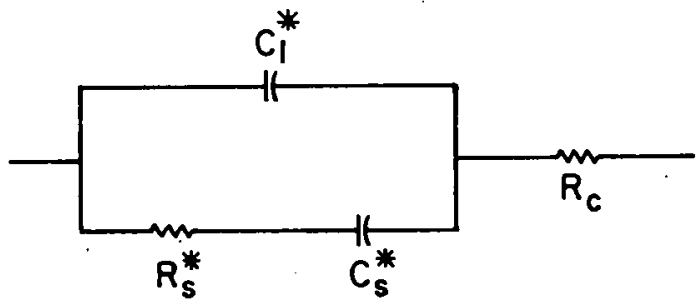

The flow of alternating current across the interface between the electrode and the solution is divided into two paths ${ }^{(3)}$; the nonfaradalc path through the charging and discharging of the electrical double layer, and the faradaic path which exists by virtue of the charge transfer due to an electrochemical process. The latter process is represented by the series combination of $R_{S}^{*}$ and $C_{s}^{*}$. Since the resistance of the electrical path between the electrodes is independent of frequency, the response of a conductivity cell to changes in the applied f'requency is determined by the capacitance of the 
electrical double layer and the nature and magnitude of the electrochemical reaction. At frequencles above $10^{4}$ cycles per second, the impedance of the electrode is determined primarlily by the capacitance of the electrical double layer, which for most metals is approximately 10 microfarads per. square centimeter ${ }^{(6)}$. Thus at high frequencles the electrical analog consists of a series combination of resistance and capacitance, and if the path of the current between the electrodes is such that $R_{c}$ is much greater than the Impedance of $C_{1}$, then the impedance of the cell should approach the true resistance of the current path between the electrodes.

There is almost universal agreement that the bridge utilized for AC impedance studies should have a serles combination of resistance and capacitance in the measuring arm; however, a parallel combination can be employed provided the results are transformed to agree with the series circuit. since bridges are not well adapted to 1n-line measurement, 1t appeared desirable to evaluate an alternative method for measuring the cell impedance. Therefore in this study, the impedance of the conductivity celí was determined by two methods: (1) bridge measurement in which the cell impedance is expressed in terms of a series combination of resistance $\left(R_{m}\right)$ and capacitance $\left(C_{m}\right)$ (F1gure 1) and (2) a constant current technique where the impedance $\left(Z_{m}\right)$ of the cell is determined directly.

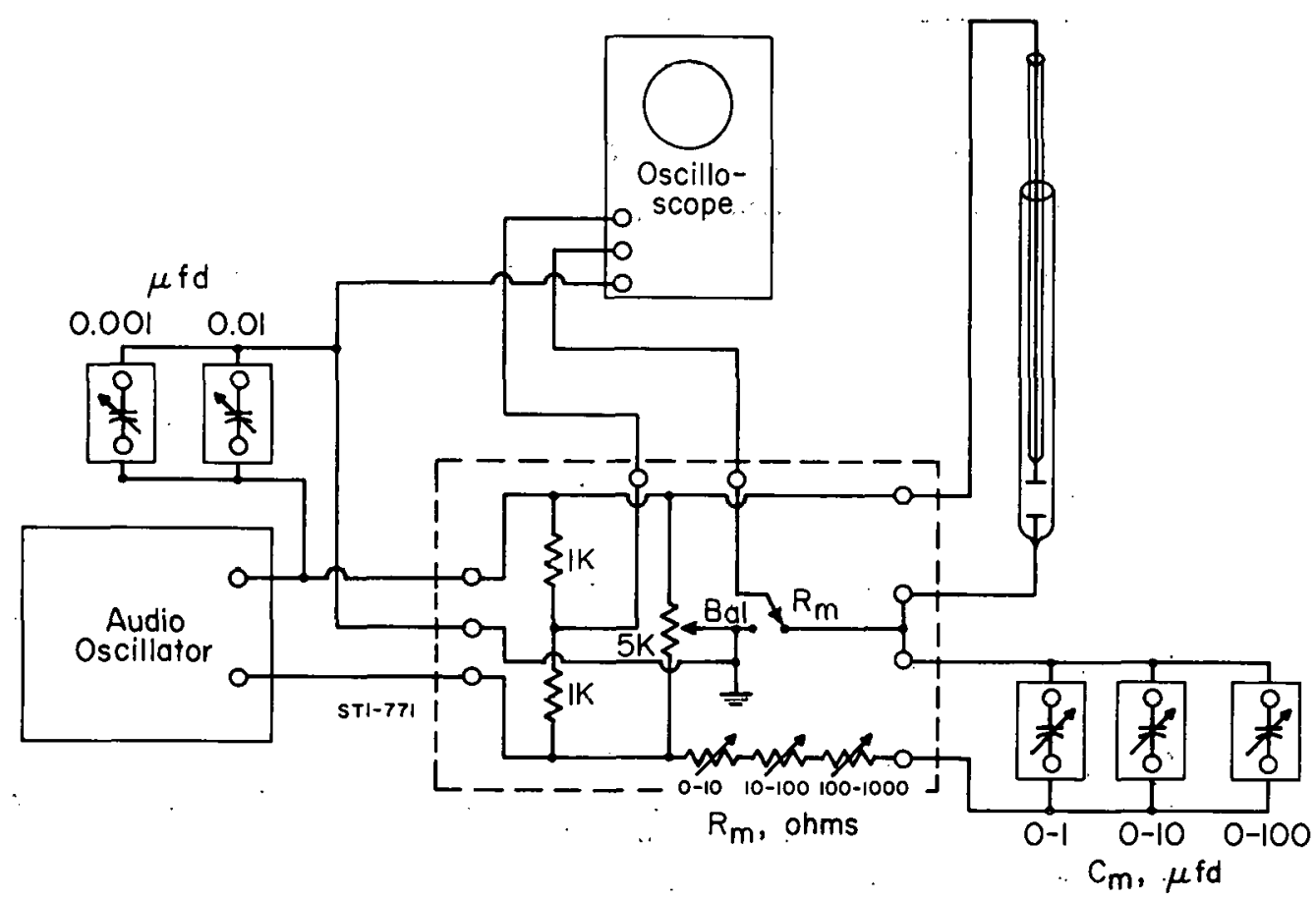

FIG. I BRIDGE APPARATUS 
In the constant current technique, the current was supplied to the cell through a large voltage dropping resistor $\left(10^{5}-10^{6}\right.$ ohms) so that the current flowing through the cell was essentially constant even though the impedance of the cell varled over a considerable range (0-200 ohms). The impedance of the cell, was calculated from the voltage drop across the cell at constant current.

\section{EQUIPMENT}

The apparatus employed for the bridge measurements is shown in Figure 1, and the apparatus for impedance measurements is shown In Figure 2. A Jackson Model 655 audio oscillator served as the signal source for both measurements. A DuMont Model $304 \mathrm{~A}$ oscilloscope served as the balance indicator for bridge measurements, and a Hewlett-Packard Model 400-C audio frequency voltmeter was ut1lized to obtain voltage measurements at constant current.

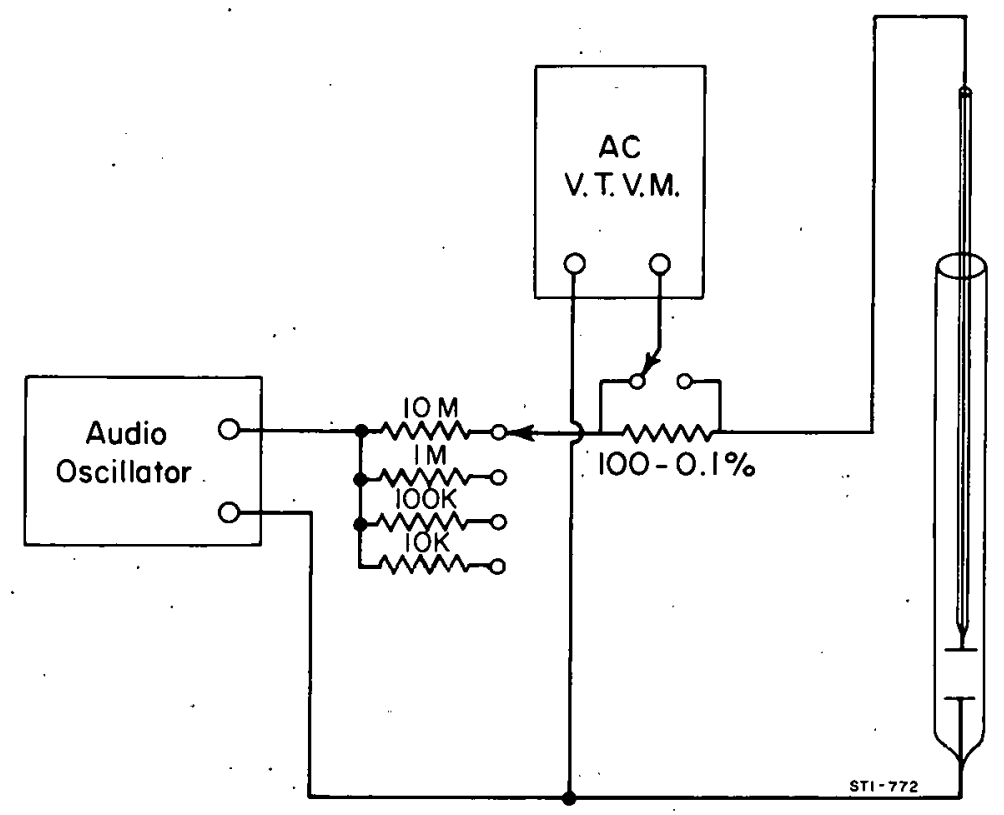

FIG. 2 APPARATUS FOR IMPEDANCE STUDIES

The output of the audio oscillator was balanced with respect to the bridge ground by means of a conventional Wagner circult. The balancing arm $\left(R_{m}-C_{m}\right)$ consisted of a series combination of resistance and capacitance to conform to the equivalent circuit concept of the conductivity cell.

Constant current measurements were made with the full output (50 volts) of the signal generator applied to the series combination of dropping resistor and conductivity cell. The 
current was calculated from the voltage drop across a precision 100-ohm resistor.

Conductivity cells were constructed as shown in Figure 3 . With the design shown in F1gures $3 a$ and $3 b$, both the electrode separation and the area of the upper electrode were varied. The effect of changes in cross-sectional area was studied with the design shown in Figure $3 b$ by substituting tubes of different diameters.

The apparatus employed in the AC 1mpedance studies, Figure 4, was essentially that described by Silverman and Remick ${ }^{(7)}$.

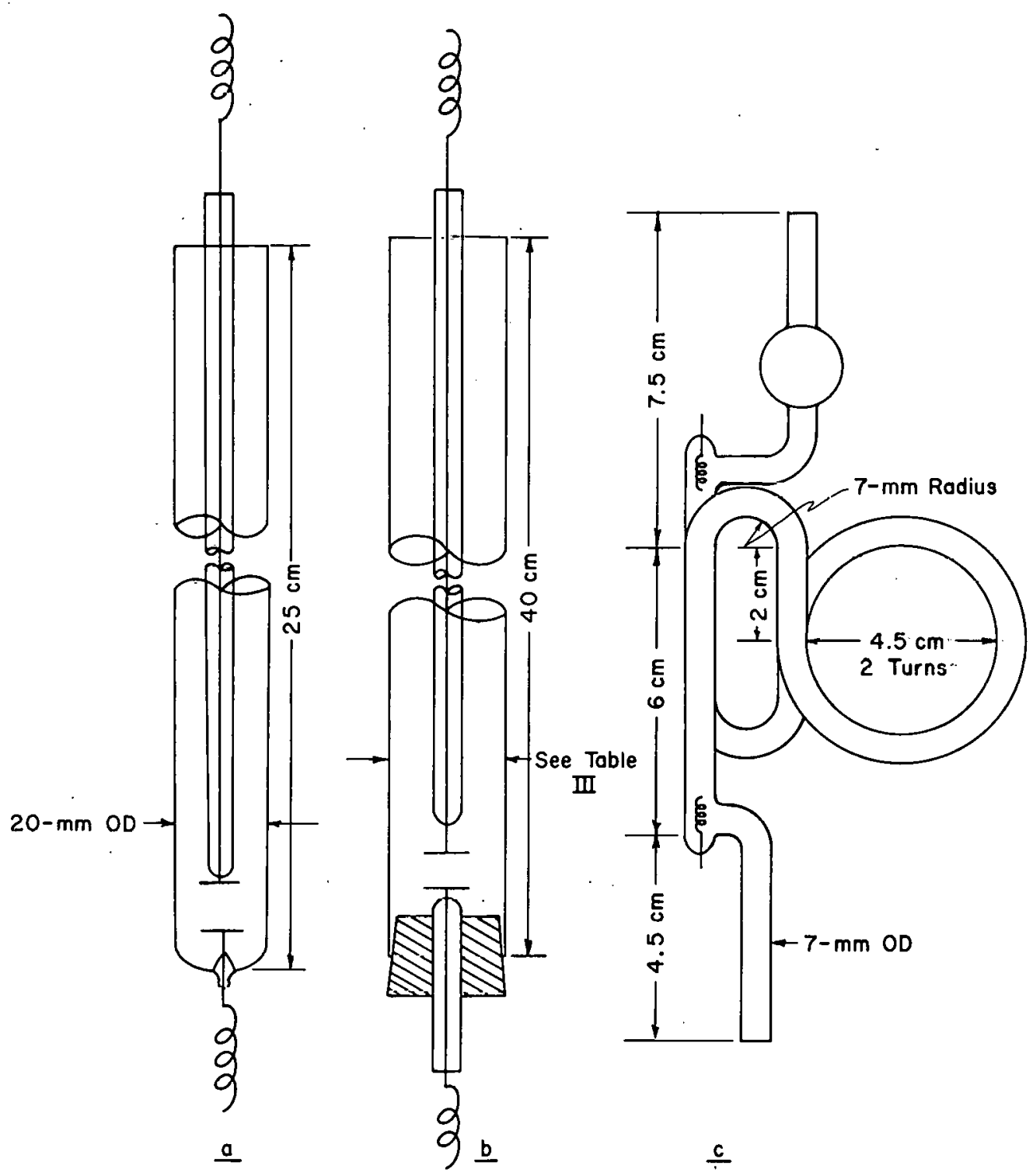

FIG. 3 CONDUCTIVITY CELLS 


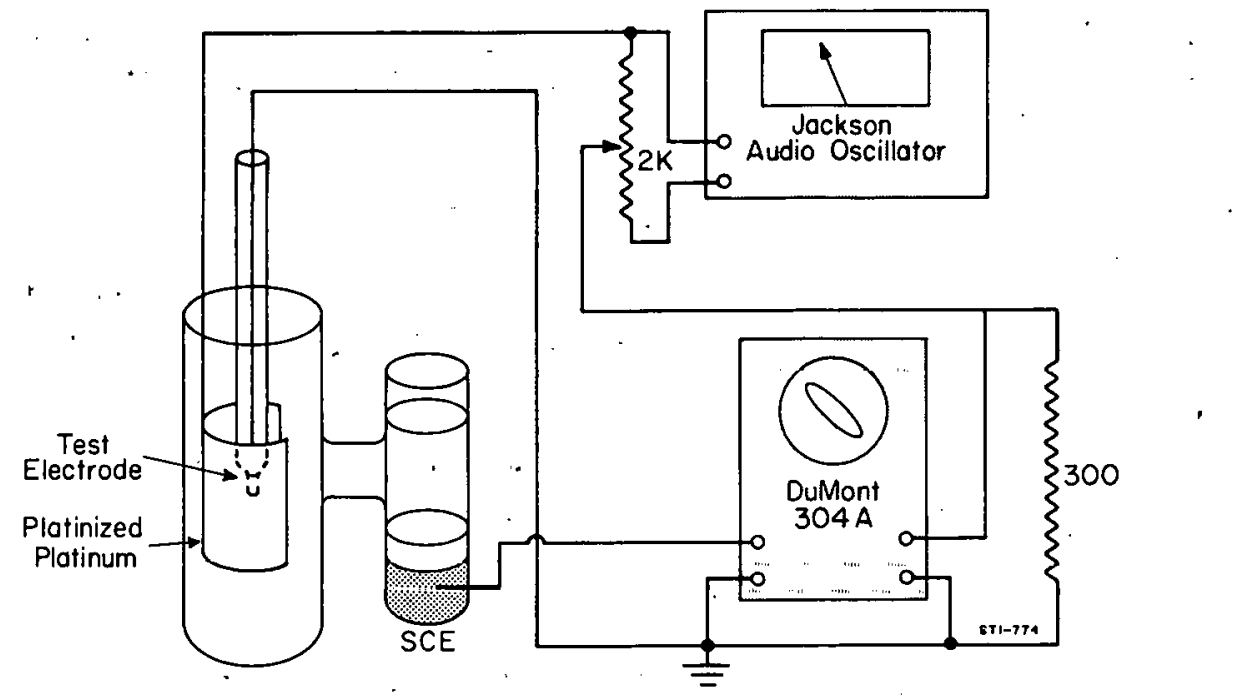

FIG. 4 ALTERNATING.CURRENT ELECTROLYSIS APPARATUS

\section{ELECTRODE SEPARATION}

The resistance of a column of solution of uniform cross section ( $R_{c}$ in the equivalent circuit) that was situated between two electrodes increased linearly with electrode separation; the effect was independent of electrode area and frequency as shown in Table $\dot{I}$.

The data for the effect of electrode separation were obtalned with the 20-mm-diameter cell shown in Figure $3 \mathrm{a}$. The cell contalned a solution of $0.14 \mathrm{M}$ uranyl nitrate that was $0.2 \mathrm{M}$ in nitric acid. The upper electrode was positioned with respect to a mililmeter scale on the side of the cell, and the distance between electrodes was read from this scale. The position and area of the lower electrode remained flxed throughout the experiments. Initially, both electrodes were of the same area. After the effect of electrode area as a function of frequency was recorded, the upper electrode was reduced in area and the experiment was repeated. The final test was made with platinized electrodes.

Bridge measurements of $R_{m}$ and $C_{m}$ were made with approximately 5 millivolts applied to the cell, and a constant current of approximately 2 microamperes was used for the impedance studies.

The data in Table I were evaluated by the method of Miller $(8, \theta)$. However, in this work the cross-sectional area of the cell was larger than the areas of the electrodes so that Miller's equation could be rewritten in terms of the crosssectional area of the cell. In the modifled equation the 
nomenclature of Miller was abandoned in favor of that used in. recent texts $(4)$. The equation for a cell of uniform cross section is as follows:

$$
R_{m}=R_{s}+\frac{\bar{R}]_{1}}{A}
$$

where $R_{m}$ = equivalent resistance of the cell as determined by bridge measurement (corresponds to $R_{S}$ in the Miller equation)

$R_{\mathrm{S}}=$ electrode polarization resistance (corresponds to $\Delta \mathrm{R}$ in the Milier equation)

$\bar{R}=$ specific resistance of solution

1 = length of column of solution between electrodes

$A=$ cross-sectional area of the column of solution

$\frac{\bar{R} I}{A}=R_{c}$ in the equlvalent circult (corresponds to $R_{t}$ in the Miller equation)

From the equation, plots of $R_{m}$ versus 1 should be linear with a slope of $\bar{R} / A$ and an intercept equal to the value of $R_{S}$. The values for $\bar{R} / A$ and $R_{S}$ were calculated from the data in Table $I$ and the values are given in Table II. The data for

TABLE I

Effect of Electrode Separation

Valuco for $F_{m}$ and $Z_{m}$ in ohms $(\Omega)$ and $c_{m}$ in microfarads $(\mu \mathrm{fd})$ as furctions of electrude area, electrode separation and frequency.

\begin{tabular}{|c|c|c|c|c|c|c|c|c|c|c|c|c|c|c|c|c|}
\hline \multirow{3}{*}{$\begin{array}{c}\text { Frequency, } \\
\text { iyy }\end{array}$} & \multirow{3}{*}{$\begin{array}{c}\text { Electrode } \\
\text { Separation, } \\
\text { cull }\end{array}$} & \multicolumn{15}{|c|}{ Area of Uoper Elechlude, $\mathrm{cm}^{2}$} \\
\hline & & \multicolumn{3}{|c|}{1.00} & \multicolumn{3}{|c|}{0.15} & \multicolumn{3}{|c|}{0.01} & \multicolumn{3}{|c|}{0.00} & \multirow{2}{*}{$\frac{0.06}{R_{m}}$} & \multicolumn{2}{|c|}{ Plallulled } \\
\hline & & $R_{m}$ & $\mathrm{C}_{\mathrm{m}}$ & $z_{m}$ & $R_{m}$ & $\mathrm{c}_{\mathrm{m}}$ & $7_{\mathrm{m}}$ & $\mathrm{R}_{\mathrm{m}}$ & $\mathrm{C}_{\mathrm{m}}$ & $7 \mathrm{~m}$ & $R_{m}$ & $\mathrm{r}_{\mathrm{m}}$ & $\mathrm{z}$ & & $r_{\mathrm{m}}$ & $z_{m}$ \\
\hline $10^{2}$ & $\begin{array}{r}1 \\
2 \\
3 \\
5 \\
7 \\
10\end{array}$ & $\begin{array}{l}13.4 \\
18.5 \\
23.3 \\
32.7 \\
42.2 \\
56.4\end{array}$ & $\begin{array}{l}35.2 \\
31.9 \\
31.0 \\
29.9 \\
29.2 \\
28.5\end{array}$ & $\begin{array}{r}92.0 \\
92.0 \\
93.0 \\
94.0 \\
94.0 \\
102\end{array}$ & $\begin{array}{l}21.2 \\
26.6 \\
31.0 \\
41.0 \\
50.8 \\
64.2\end{array}$ & $\begin{array}{l}26.6 \\
26.0 \\
25.3 \\
24.9 \\
24.6 \\
24.4\end{array}$ & $\begin{array}{l}109 \\
118 \\
119 \\
122 \\
122 \\
127\end{array}$ & $\begin{array}{l}24.3 \\
29.3 \\
33.3 \\
42.7 \\
51.8 \\
65.8\end{array}$ & $\begin{array}{l}28.4 \\
29.7 \\
28.1 \\
27.4 \\
26.6 \\
26.3\end{array}$ & $\begin{array}{r}67.7 \\
84.0 \\
91.0 \\
88.0 \\
96.0 \\
105\end{array}$ & $\begin{array}{l}27.3 \\
32.1 \\
35.3 \\
46.2 \\
55.6 \\
69.3\end{array}$ & $\begin{array}{l}22.0 \\
21.3 \\
21.0 \\
20.5 \\
20.5 \\
20.4\end{array}$ & $\begin{array}{l}121 \\
129 \\
132 \\
132 \\
129 \\
136\end{array}$ & $\begin{array}{l}10.6 \\
15.8 \\
20.4 \\
29.6 \\
39.8 \\
54.1\end{array}$ & $\begin{array}{l}8000 \\
8000 \\
8000 \\
7500 \\
7500 \\
6500\end{array}$ & $\begin{array}{r}9.4 \\
13.6 \\
14.4 \\
27.4 \\
37.8 \\
52.5\end{array}$ \\
\hline $10^{3}$ & $\begin{array}{r}1 \\
2 \\
3 \\
5 \\
7 \\
10\end{array}$ & $\begin{array}{r}8.4 \\
13.3 \\
18.2 \\
27.6 \\
37.3 \\
51.0\end{array}$ & $\begin{array}{l}20.4 \\
20.6 \\
20.7 \\
20.9 \\
21.0 \\
20.8\end{array}$ & $\begin{array}{l}10.6 \\
14.0 \\
18.4 \\
27.4 \\
36.8 \\
48.0\end{array}$ & $\begin{array}{l}11.6 \\
16.5 \\
21.0 \\
30.5 \\
40.5 \\
54.2\end{array}$ & $\begin{array}{l}15.1 \\
15.0 \\
14.6 \\
14.5 \\
14.3 \\
14.5\end{array}$ & $\begin{array}{l}15.5 \\
19.3 \\
22.3 \\
30.8 \\
40.2 \\
52.5\end{array}$ & $\begin{array}{l}14.2 \\
19.7 \\
23.6 \\
33.2 \\
42.4 \\
56.9\end{array}$ & $\begin{array}{l}18.8 \\
18.6 \\
18.6 \\
18.4 \\
18.4 \\
18.4\end{array}$ & $\begin{array}{l}15.2 \\
19.2 \\
23.3 \\
31.8 \\
41.3 \\
50.0\end{array}$ & $\begin{array}{l}17.5 \\
22.1 \\
27.0 \\
36.7 \\
46.2 \\
60.1\end{array}$ & $\begin{array}{l}14.4 \\
14.2 \\
14.2 \\
14.2 \\
14.1 \\
14.1\end{array}$ & $\begin{array}{l}19.4 \\
23.1 \\
28.0 \\
36.6 \\
41.1 \\
59.2\end{array}$ & $\begin{array}{l}10.4 \\
15.8 \\
20.3 \\
29.6 \\
39.5 \\
53.9\end{array}$ & $\begin{array}{l}2500 \\
2500 \\
2500 \\
2500 \\
2500 \\
2500\end{array}$ & $\begin{array}{r}9.3 \\
13.6 \\
18.8 \\
28.1 \\
37.6 \\
52.0\end{array}$ \\
\hline $10^{4}$ & $\begin{array}{r}1 \\
2 \\
3 \\
5 \\
7 \\
10\end{array}$ & $\begin{array}{r}7.3 \\
12.1 \\
16.8 \\
26.5 \\
35.6 \\
50.0\end{array}$ & $\begin{array}{l}12.3 \\
14.5 \\
12.5 \\
12.6 \\
13.7 \\
12.0\end{array}$ & $\begin{array}{r}5.8 \\
10.8 \\
15.0 \\
23.3 \\
33.4 \\
45.6\end{array}$ & $\begin{array}{r}8.6 \\
13.5 \\
18.1 \\
27.7 \\
37.3 \\
51.0\end{array}$ & $\begin{array}{l}8.2 \\
9.0 \\
8.0 \\
7.7 \\
7.9 \\
7.5\end{array}$ & $\begin{array}{r}7.9 \\
12.0 \\
16.2 \\
26.1 \\
35.0 \\
47.6\end{array}$ & $\begin{array}{l}10.8 \\
15.8 \\
20.3 \\
30.3 \\
39.7 \\
53.7\end{array}$ & $\begin{array}{l}7.2 \\
7.0 \\
7.0 \\
6.6 \\
6.6 \\
6.6\end{array}$ & $\begin{array}{r}9.1 \\
11.8 \\
18.9 \\
27.8 \\
36.5 \\
50.8\end{array}$ & $\begin{array}{l}13.3 \\
17.9 \\
22.4 \\
32.2 \\
41.0 \\
55.5\end{array}$ & $\begin{array}{l}5.3 \\
5.3 \\
5.3 \\
5.2 \\
5.2 \\
5.2\end{array}$ & $\begin{array}{l}11.2 \\
18.8 \\
20.9 \\
29.8 \\
38.6 \\
51.0\end{array}$ & $\begin{array}{l}10.4 \\
15.4 \\
20.3 \\
30.1 \\
39.3 \\
53.4\end{array}$ & $\begin{array}{l}1000 \\
1000 \\
1000 \\
1000 \\
1000 \\
1000\end{array}$ & $\begin{array}{r}8.7 \\
13.3 \\
18.1 \\
27.3 \\
38.0 \\
52.2\end{array}$ \\
\hline $10^{5}$ & $\begin{array}{r}1 \\
2 \\
3 \\
5 \\
7 \\
10\end{array}$ & $\begin{array}{r}9.3 \\
12.1 \\
16.7 \\
25.7 \\
35.6 \\
51.0\end{array}$ & $\begin{array}{l}0.5 \\
5.0 \\
0.9 \\
1.0 \\
0.8 \\
0.5\end{array}$ & $\begin{array}{r}5.9 \\
10.6 \\
14.6 \\
23.4 \\
32.2 \\
45.8\end{array}$ & $\begin{array}{r}8.6 \\
13.8 \\
17.7 \\
27.0 \\
37.1 \\
51.0\end{array}$ & $\begin{array}{l}0.6 \\
1.8 \\
0.7 \\
0.7 \\
0.7 \\
0.5\end{array}$ & $\begin{array}{r}6.4 \\
9.1 \\
15.7 \\
25.0 \\
34.5 \\
50.0\end{array}$ & $\begin{array}{r}9.3 \\
14.4 \\
18.0 \\
28.9 \\
37.6 \\
51.0\end{array}$ & $\begin{array}{l}0.5 \\
0.8 \\
0.5 \\
0.4 \\
0.5 \\
0.4\end{array}$ & $\begin{array}{r}8.4 \\
12.2 \\
16.8 \\
25.9 \\
35.9 \\
47.5\end{array}$ & $\begin{array}{l}10.0 \\
16.0 \\
20.4 \\
30.3 \\
39.7 \\
54.0\end{array}$ & $\begin{array}{l}0.4 \\
0.5 \\
0.5 \\
0.4 \\
0.4 \\
1.0\end{array}$ & $\begin{array}{r}9.3 \\
10.4 \\
17.2 \\
27.9 \\
36.4 \\
48.8\end{array}$ & $\begin{array}{l}10.4 \\
15.2 \\
20.3 \\
30.3 \\
39.3 \\
53.8\end{array}$ & $\begin{array}{l}1.0 \\
1.0 \\
0.6 \\
0.5 \\
0.6 \\
0.8\end{array}$ & $\begin{array}{r}9.3 \\
12.7 \\
17.3 \\
26.8 \\
36.5 \\
51.8\end{array}$ \\
\hline
\end{tabular}


a. Values for $\bar{R} / A$ and $\bar{z} / A$

\begin{tabular}{|c|c|c|c|c|c|c|c|c|c|c|}
\hline \multirow{3}{*}{$\begin{array}{c}\text { Frequency, } \\
\text { cps }\end{array}$} & \multicolumn{10}{|c|}{ Area of Upper Electrode, $\mathrm{cm}^{2}$} \\
\hline & \multicolumn{2}{|c|}{1.0} & \multicolumn{2}{|c|}{0.45} & \multicolumn{2}{|c|}{0.21} & \multicolumn{2}{|c|}{0.06} & \multicolumn{2}{|c|}{0.06 Platin1zed } \\
\hline & $\bar{R} / A(a)$ & $\underline{\bar{z} / A^{(a)}}$ & $\bar{R} / A$ & $\bar{z} / A$ & $\overline{\mathrm{R}} / \mathrm{A}$ & $\underline{\bar{z} / A}$ & $\overline{\mathrm{R}} / \mathrm{A}$ & $\underline{\bar{z}} / \mathrm{A}$ & $\overline{\mathrm{R} / \mathrm{A}}$ & $\underline{\bar{z} / \mathrm{A}}$ \\
\hline $10^{2}$ & 4.75 & (b) & 4.82 & 1.2 & 4.61 & (b) & 4.67 & (b) & 4.83 & 4.8 \\
\hline $10^{3}$ & 4.70 & 4.3 & 4.70 & 4.1 & 4.70 & 3.7 & 4.70 & 4.4 & 4.83 & 4.7 \\
\hline $10^{4}$ & 4.75 & 4.4 & 4.70 & 4.5 & 4.67 & 4.5 & 4.68 & 4.2 & 4.70 & 4.8 \\
\hline $10^{5}$ & 4.75 & 4.4 & 4.70 & 4.5 & 4.65 & 4.4 & 4.71 & 4.4 & 4.82 & 4.7 \\
\hline
\end{tabular}

b. Values for $R_{g}$ and $z_{s}$

\begin{tabular}{|c|c|c|c|c|c|c|c|c|c|c|}
\hline & ${ }_{\mathrm{g}}{ }^{(c)}$ & $z_{g}^{(c)}$ & $\mathrm{R}_{\mathrm{s}}$ & $z_{8}$ & $R_{s}$ & $\mathrm{z}_{\mathrm{B}}$ & $R_{B}$ & $z_{8}$ & $\mathrm{R}_{\mathrm{s}}$ & $z_{8}$ \\
\hline $.0^{2}$ & 8.9 & 91.6 & 16.8 & 115.3 & 19.6 & (d) & 22.6 & (d) & 5.9 & 3.0 \\
\hline $10^{3}$ & 3.8 & 6.3 & 7.0 & 11.0 & 10.0 & 12.7 & 13.0 & 14.6 & 5.9 & 3.0 \\
\hline $10^{4}$ & 2.6 & 1.6 & 4.0 & 3.4 & 6.5 & 4.9 & 8.7 & 8.6 & 5.9 & 3.0 \\
\hline $0^{5}$ & 2.6 & 1.6 & 4.0 & 1.7 & 4.9 & 3.8 & 5.8 & 5.5 & 5.9 & 3.0 \\
\hline
\end{tabular}

(a) values for $\bar{K} / A$ and $\bar{Z} / A$ in ohms-centimeters $(\Omega-\mathrm{cm})$ were calculated from data in Table I.

(b) Plots of $Z$ vB $l$ were nonlinear.

(c) Values for $R_{g}$ and $z_{\beta}$ in ohms $(\Omega)$ were obtalned from data in Table I by extrapolation of $\mathrm{K}_{\mathrm{m}}$ and $z_{\mathrm{m}}$ to Zero Interelectrode Distance.

(d) Data exh1bit too much dispersion to permit accurate estimate.

cell Impedance $\left(Z_{m}\right)$ versus electrode separation were evaluated In a like manner. In this case, the intercept corresponds to the combined impedance of the electrodes. These results are also given in Table IIa.

The data on the uranyl nitrate - nitric acid system show that the calculated values of $\bar{R} / A$ for a cell of constant cross section were independent of electrode area and frequency. The calculated values of $\bar{Z} / A$ were also a function of electrode separation and were independent of electrode area and applied frequency above 1000 cycles per second. However, the values for $\bar{Z} / A$ were lower than the corresponding values of $\bar{R} / A$ except in the case of platinized electrodes. This result is in accord with the equivalent circuit concept of a conductivity cell. Therefore bridge measurements are required where accurate values of $\bar{R} / A$ must be obtained.

\section{CROSS-SECTIONAL AREA OF SOLUTION}

In view of the linear dependence of $R_{m}$ on electrode separation, it appeared desirable to establish the relationship between $R_{m}$ and $A$. Since $1 t$ was loglcal to conclude that the relationship of $R_{I I}$ to $\Lambda$ would fall for large values of $A$ and small electrode areas, tubing of the largest diameter immediately available was utilized in the fabrication of one of the cells.

The type of cell utilized for the area studies is shown in Figure 3b. All cells were $400 \mathrm{~mm}$ in length except for the 
90-mm cell, which was $500 \mathrm{~mm}$ long. The cross-sectional areas are given in Table III. The electrodes were bright platinum plates $1 \mathrm{~cm}$ in diameter. The applied frequency was $10 \mathrm{kc}$.

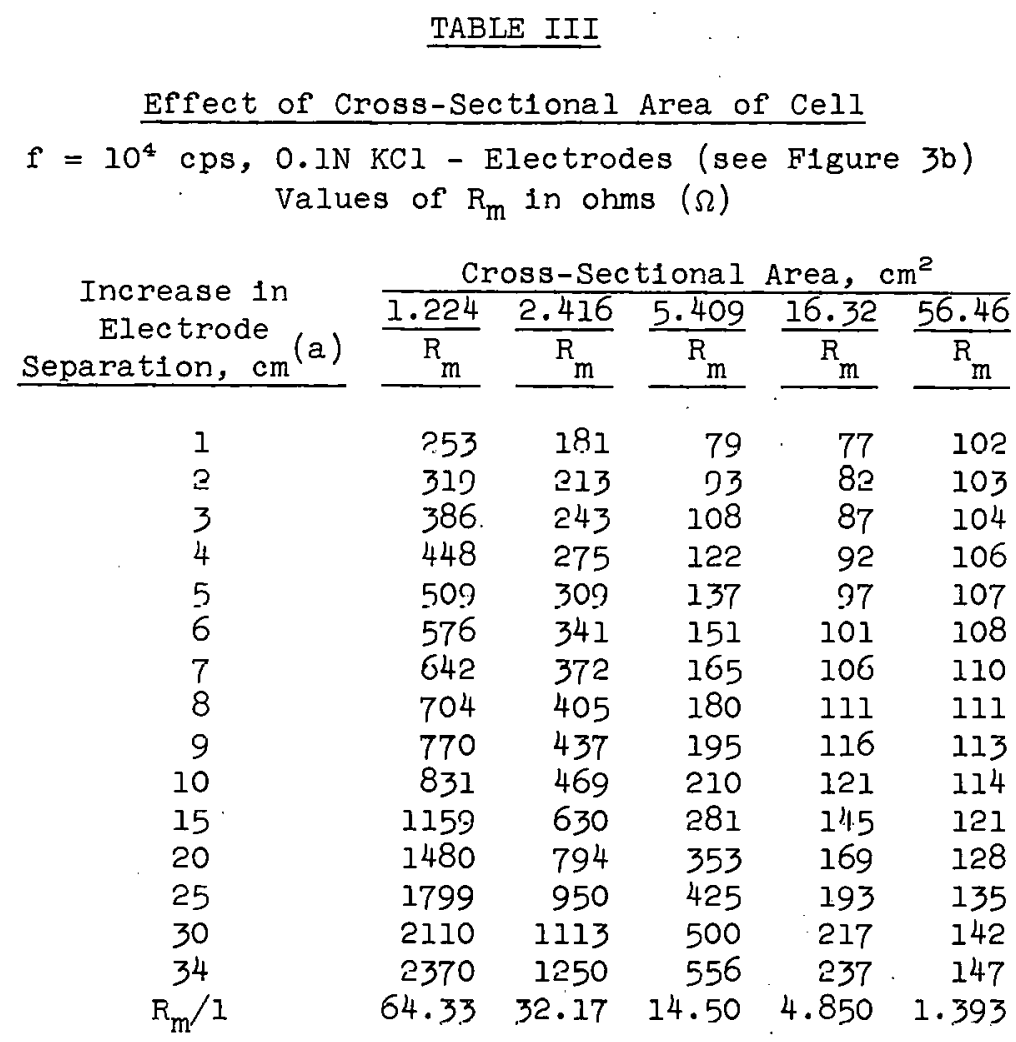

(a) Readings at an initial electrode separation of $2-5 \mathrm{~cm}$ depending on the diameter of the tube.

The cross-sectional areas of the cells were determined by adding measured volumes of water to each cell and recording the increase in helght from the millimeter scale. The coefficient of variation of this method was $1 \%$. Data for the effect of electrode separation on $R_{m}$ for cells of different cross sections are given in Table III.

Calculated values for $\bar{R} / A$ obtained from the data in Table III, cross-sectional areas of the cells, and the calculated values for $\bar{R}$ are given in Table IV.

The results show that the value for $R_{c}$ in the equivalent circuit can be calculated from the geometry of the solution between the electrodes and the specific resistance $\bar{R}$, and that the technique of electrode separation permits the specific resistance of a solution to be determined within $1 \%$, independent of electrode area. 
$\underline{\text { TABLE IV }}$

Effect of Cell Cross Section

$f=10 \mathrm{kc}, 0.1 \mathrm{~N} \mathrm{KCl}-$ Electrodes (see Figure $3 \mathrm{~b}$ )

Cell No.

Cross-sectional area of cell, $\mathrm{cm}^{2}$

$\overline{\mathrm{R}} / \mathrm{A}, \Omega-\mathrm{cm}$

$\bar{R}, \Omega-\mathrm{cm}$

$\overline{\mathrm{R}}$ (avg), $\Omega-\mathrm{cm}$

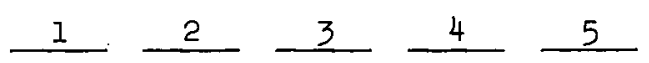

$\begin{array}{lllll}1.23 & 2.42 & 5.41 & 16.3 & 56.5\end{array}$

$\begin{array}{lllll}64.3 & 32.2 & 14.5 & 4.85 & 1.39\end{array}$

$\begin{array}{lllll}79.1 & 77.9 & 78.4 & 79.0 & 78.4\end{array}$

$78.6 \pm 0.5$

\section{ELECTRODE AREA}

The impedance of the conductivity cell increased with decreasing area of the upper electrode; however, the $50 \%$ change in impedanse was considerahly less than anticipated in view of the $1600 \%$ change in the area of the upper electrode.

Data for the effect of electrode area are giver in Tables I and II, and curves for the effect of electrode area at zero separation are shown in Figure 5. These data were obtained as previously described, and the areas given in the tables are for the upper electrode only. The area of the lower electrode was $1 \mathrm{~cm}^{2}$.
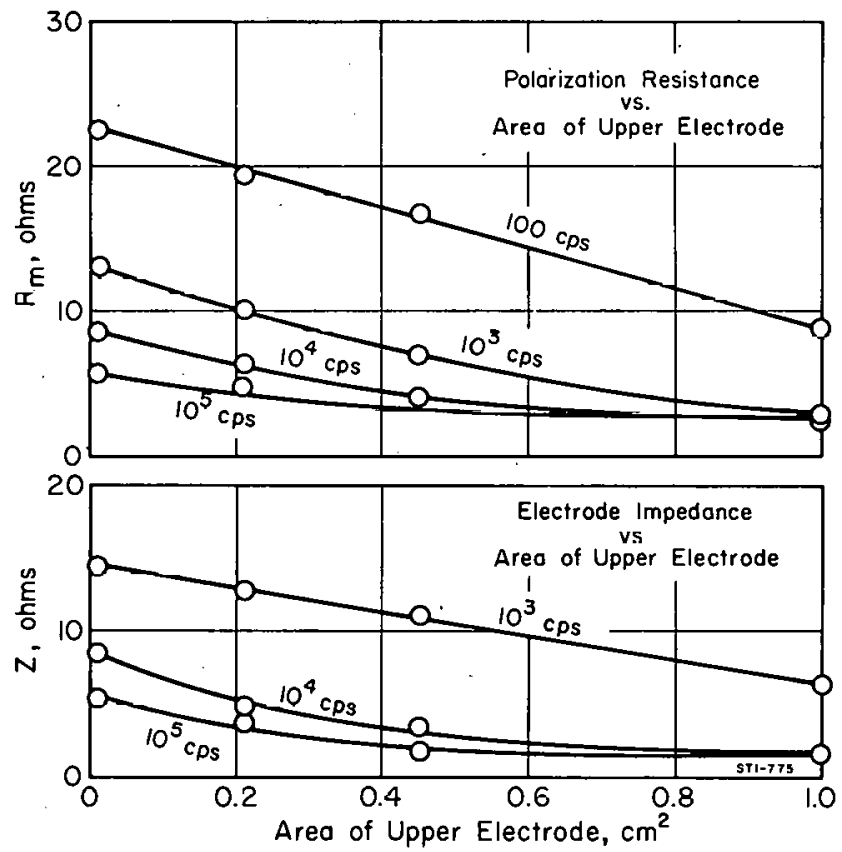

FIG. 5 EFFECT OF ELECTRODE AREA AT ZERO INTERELECTRODE DISTANCE

Results from data given in Table 1 
The results show that the electrode impedance and polarlation resistance decrease nonlinearly with increasing area, and that the effect, which was a function of the applied frequency, decreased as the frequency was increased. Normally the polarization resistance $R_{S}$ and reactances of $C_{S}$ and $C_{I}$ are expected to be inverse functions of the electrode area $(4)$. Although the reasons for the anomalous behavior are not immediately apparent, the results indicate the importance of electrode area in the design of conductivity cells.

\section{FREQUENCY}

The response of a conductivity cell to changes in the applied frequency car be interpreted in terms of the contemporary theory of faradaic admittance( 3$)$. In the design of conductivity cells, the Impedances of the elements $R_{S}, C_{S}$, and $C_{I}$ in the equivalent circuit that are dependent on frequency must be minimized in order for the measured response to be truly indicative of the resistance of the current path. Therefore the results in Table I were evaluated in terms of the contemporary theory.

Values for the frequency-dependent term $R_{S}$ were obtained from the data in Table $I$ by extrapolating the curves of $R_{m}$ versus electrode separation to zero distance. These results are given in Table IIb. Due to the dispersion of the values of $C_{m}$, no results for $C_{m}$ at zero electrode separation are given in Table II. The dispersion in the values for $C_{m}$ is not surprising since a lengthy pretreatment and extreme care are necessary to obtain reproducible results for $C_{m}$ with solid electrodes $(\%)$. No special treatment was given to the electrodes during this study since one of the objectives was to demonstrate that the electrodes in a conductivity cell do not have to be scrupulously clean for in-line conductivity measurements.

The results show that the polarization resistance $R_{S}$ and the electrode impedance ( $z_{\mathrm{s}}$ at zero separation) decrease with increasing frequency and approach constant values at $100 \mathrm{kc}$. Curves of $R_{S}$ versus the reciprocal of the square root of frequency were linear in agreement with the theory of faradaic admittance.

In view of the dispersion in the observed values of $C_{m}$ which did not permit extrapolation to zero electrode separation, this variable was studied at a separation of $5 \mathrm{~mm}$. Curves of $\mathrm{C}_{m}$ versus $\mathrm{log}$ frequency were essentially linear with the capacity decreasing with increasing frequency. 
The above results are consistent with the contemporary theory of faradaic admittance, and indicate that the effects of electrode impedance on the response of a conductivity cell can be minimized by utilizing frequencles in the range of $10^{4}$ to $10^{5}$ cycles per second.

\section{PLATINIZED ELECTRODES}

A platinized electrode behaves as a reversible hydrogen electrode ${ }^{(6)}$, and the contemporary theory of faradalc admittance predicts that the impedance of an electrode will be minimum at the half-wave potential of the electrochemical reaction.

Data for the effect of electrode platinlzation are given in Table $I$. The area of the upper electrode was $0.06 \mathrm{~cm}^{2}$. Curves for $R_{S}$ and $C_{S}$ at zero separation versus $f-\frac{1}{2}$ are shown in Figure 6 , and extrapolated values for $R_{S}$ and $Z_{S}$ at zero separation are given in Table II.

The theory for alternating current electrolysis $(4)$ predicts that the polarization resistance of an electrode 1 s minimum at the half-wave potential of the controlling electrochemical reaction and that the pseudocapacitance $\left(\mathrm{C}_{\mathrm{S}}\right)$ will be maximum at that potential. The theory also predicts that for fast, reactions both $R_{S}$ and $C_{S}$ will decrease as a function of $\mathrm{f}^{-\frac{1}{2}}$. The curves in Figure 6 show that $C_{S}$ decreased as a function of $f^{-\frac{1}{2}}$, whereas $R_{S}$ was essentially constant. This behavior of $R_{S}$ was indicative of a slow reaction.

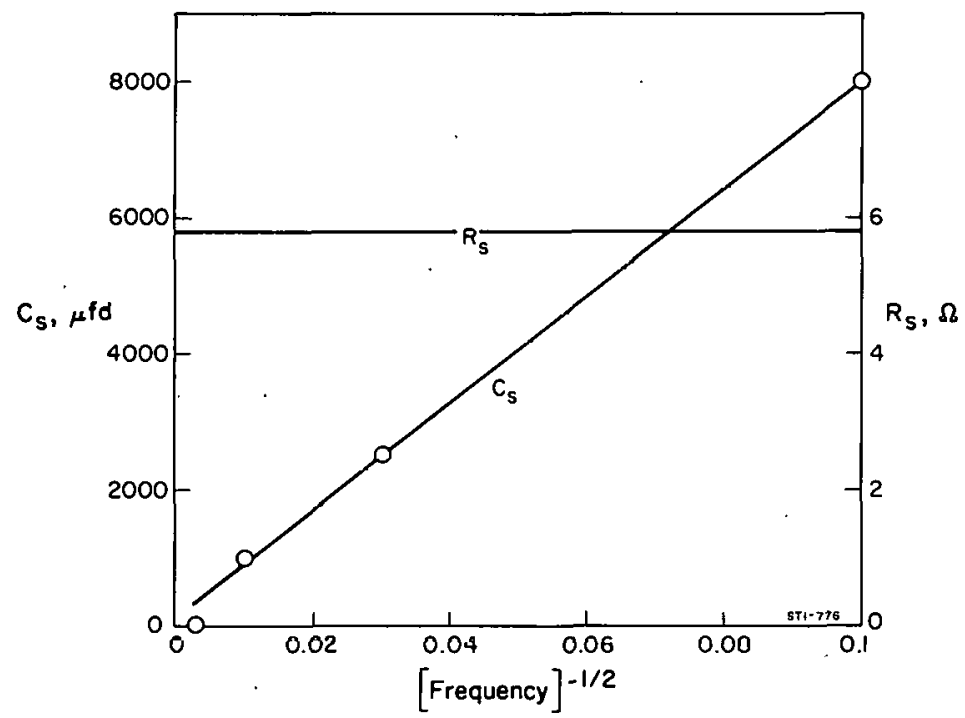

FIG. 6 EFFECT OF PLATINIZED ELECTRODES Values of $R_{S}$ and $C_{S}$ versus $f^{-1 / 2}$ Results calculated from data given in Table I by extrapolating $R_{m}$ and $C_{m}$ to zero interelectrode distance. 
The results indicate that platinized platinum electrodes are desirable for conductivity cells; however, the results observed with bright platinum electrodes at $10^{5} \mathrm{cps}$ agree with those obtained with platinized electrodes. Therefore the . necessity for platinized electrodes can be eliminated by utilizing high frequencies.

\section{AMPLITUDE OF CELL VOLTAGE}

Since the amplitude of the cell voltage is one of the factors that determines the extent of the electrochemical reaction that occurs at the electrodes, the effect of the amplitude variable was studied at four frequencles with the cell shown in ligure 3a: The areas of the upper and lower. electrodes were 0.06 and $1.0 \mathrm{~cm}^{2}$, respectively, and the electrodes were positioned $1 \mathrm{~cm}$ apart. Cell voltages were monitored by means of an $A C$ voltmeter; and $R_{m}$. $r_{m}$, and $7_{\text {III }}$ were determined as a function of cell voltage. . The results are given in Table $\mathrm{V}$.

\section{TABLE V}

Effect of Amplitude of Cell Voltage

\begin{tabular}{|c|c|c|c|c|c|c|c|c|c|c|}
\hline \multirow[b]{4}{*}{$\begin{array}{c}\text { Frequency, } \\
\text { cps }\end{array}$} & \multicolumn{10}{|c|}{$\begin{array}{c}\text { Area upper electrode } 0.06 \mathrm{~cm}^{2} \text {, Area lower electrode } 1 \mathrm{~cm}^{2} \\
\text { Interelectrode distance } 1 \mathrm{~cm} \text {, Cell shown In F1gure } 3 \mathrm{a} \\
0.14 \mathrm{M} \text { UNH }-0.2 \mathrm{M} \text { HNO }_{3}\end{array}$} \\
\hline & \multicolumn{5}{|c|}{ - Platinized Electrodes } & \multicolumn{5}{|c|}{ Bright Platinum Electrodes } \\
\hline & \multicolumn{3}{|c|}{ Bridge } & \multirow{2}{*}{$\begin{array}{l}\text { Constant } \\
\text { Eells } \\
\text { V, RMS } \\
\end{array}$} & \multirow{2}{*}{$\mathrm{Z}_{\mathrm{m}}, \Omega$} & \multicolumn{3}{|c|}{ Bridge } & \multirow{2}{*}{$\begin{array}{l}\text { Constant } \\
\text { Ecell' } \\
\text { V, RMS }\end{array}$} & \multirow[b]{2}{*}{$\mathrm{z}_{\mathrm{m}}, \Omega$} \\
\hline & $\begin{array}{l}E_{\text {cell' }} \\
\mathrm{V}, \mathrm{RMS}\end{array}$ & ${ }_{\mathrm{m}}, \Omega$ & $\begin{array}{l}{ }^{C} m^{\prime} \\
\mu f d\end{array}$ & & & $\begin{array}{l}\text { Ecell' } \\
\text { V, RMS } \\
\end{array}$ & $\mathrm{R}_{\mathrm{m}}, \Omega$ & $\begin{array}{l}\mathrm{C}_{\mathrm{m}^{\prime}} \\
\mu \mathrm{fo}^{\prime}\end{array}$ & & \\
\hline \multirow[t]{6}{*}{$10^{2}$} & 0.0042 & 10.4 & 8000 & 0.00012 & 11.5 & 0.0082 & 25.7 & 24 & 0.00012 & $7 / 2$ \\
\hline & 0.076 & 10.4 & 8000 & 0.00054 & 9.1 & 0.027 & 25.9 & 2 니 & 0.00032 & 50 \\
\hline & 0.08 & 10.4 & 8000 & 0.0027 & 10.8 & 0.092 & 26.8 & 25 & 0.0099 & 51 \\
\hline & 0.29 & 10.7 & 6000 & 0.023 & 10.6 & 0.29 & 20.3 & 58 & 0.034 & 52 \\
\hline & 1.00 & 10.7 & 6500 & 0.084 & 9.2 & 0.92 & 13.4 & 215 & 0.22 & 28 \\
\hline & 1.74 & 10.7 & 6500 & 0.39 & 10.5 & 2.25 & 11.5 & 390 & 1.1 & 15 \\
\hline \multirow[t]{6}{*}{$10^{3}$} & 0.0062 & 10.4 & 1500 & $0.0002^{4}$ & 10.6 & 0.008 & 11.2 & 25 & 0.00030 & 12.6 \\
\hline & 0.040 & 10.4 & 2000 & 0.00072 & 10.3 & 0.029 & 11.2 & 24 & 0.0010 & 11.9 \\
\hline & 0.020 & 10.4 & 3000 & 0.0026 & 10.5 & 0.096 & 11.2 & 25 & 0.0036 & 14.6 \\
\hline & 0.70 & 10.4 & 7000 & 0.026 & 10.3 & 0.29 & 11.2 & 30 & 0.011 & 12.4 \\
\hline & 1.92 & 10.4 & 24000 & 0.26 & 10.4 & 0.90 & 10.4 & 55 & 0.11 & 12.7 \\
\hline & & & & 0.58 & 10.5 & 2.1 & 10.0 & 100 & 1.0 & 11.2 \\
\hline \multirow[t]{6}{*}{$10^{4}$} & $0.007^{4}$ & 10.4 & 4000 & 0.00019 & 10.4 & 0.0071 & 10.0 & 15 & 0.00027 & 10.7 \\
\hline & 0.022 & 10.4 & 4000 & 0.00084 & 9.5 & 0.029 & 10.0 & 14 & 0.00095 & 10.5 \\
\hline & 0.09 & 10.4 & 4000 & 0.ก०26 & 10.6 & 0.096 & 10.0 & 14 & 0.0050 & 11.1 \\
\hline & 0.27 & 10.4 & 8000 & 0.0084 & 9.7 & 0.30 & 10,0 & 13 & 0.040 & 10.9 \\
\hline & 0.81 & 10.4 & 20000 & 0.029 & 10.7 & 1.0 & $9: 7$ & 13 & 0.098 & 10.8 \\
\hline & & & & 0.59 & 10.5 & 1.8 & $9 \cdot 7$ & 13.5 & 0.65 & 10.8 \\
\hline \multirow[t]{5}{*}{$10^{5}$} & 0.0066 & 10.4 & 3 & 0.00024 & 10.9 & 0.0025 & 10.0 & 0.4 & 0.00030 & 11.0 \\
\hline & 0.027 & 10.4 & 7 & 0.00082 & 11.6 & 0.0092 & 10.0 & 0.5 & 0.00082 & 11.4 \\
\hline & 0.091 & 10.4 & 8 & 0.0030 & 11.1 & 0.030 & 10.0 & 0.5 & 0.0095 & 10.5 \\
\hline & 0.24 & 10.4 & 8 & 0.029 & 10.7. & 0.10 & 10.0 & 0.5 & 0.098 & 10.8 \\
\hline & 0.30 & 10.4 & $\cdot 8$ & 0.12 & 10.5 & 0.29 & 10.0 & 0.5 & 0.129 & $10: 8$ \\
\hline
\end{tabular}


The results indicate that the resistance $\left(R_{m}\right)$ and impedance $\left(Z_{m}\right)$ of a cell with bright platinum electrodes were essentially independent of cell voltage in the frequency range of $10^{3}$ to $10^{5} \mathrm{cps}$. Below $10^{3} \mathrm{cps}$, the values for $R_{m}$ and $Z_{m}$ decreased with increasing voltage and approached the values obtained at higher frequencies. An explanation of this behavior, which is in accord with the theory of faradaic admittance, was given by Silverman and Remick(7).

For platinized electrodes, the values of $R_{m}$ and $Z_{m}$ were independent of frequency and applied voltage, while the values of $\mathrm{C}_{\mathrm{m}}$ increased with applied voltage except at $10^{5} \mathrm{cps}$ where the values for $C_{m}$ abruptly decreased in value. This behavior of the platinized electrode system is in accord with the concept of polarized electrodes operated at the half-wave potential of the electrochemical reaction that occurs at the electrode surface. The decrease in $C_{m}$ at $10^{5} \mathrm{cps}$ was characteristic of the behavior of platinized electrodes (see Figure 6).

The above results indicate thal, will approximatcly 2 volts applied to the cell, the conductivity results would be independent of frequency. However, Silverman and Remick(7) have shown that at high current densities the electrode is polarized; therefore, for processes other than lhose involving reversible reactions, large errors can result due to polarization. Thus the high frequency - low voltage technique appears advantageous for use with those systems that do not involve reversible reactions at the electrodes.

\section{ELECTRODE MATERIALS}

The polarization impedance of various electrode materials in $0.14 \mathrm{M}$ uranyl nitrate - $0.2 \mathrm{~N}$ nitric acid was studied qualitatively by the method of Silverman and Remick(7). The impedance of the electrodes increased in this order: platinized platinum, platinum, stainless steel, and tantalum.

The apparatus utilized for these studies is shown in Figure 4, and typical cyclograms are shown in Figure 7 .

At low current densities, the cyclograms were elliptical which indicates that the polarization resistance and capacitance did not change significantly with changes in cell current. If the reaction rate had changed significantly with voltage, the cyclograms would have been distorted. The impedance of the various electrodes was determined from the slope of the cyclograms. The cyclograms for platinized electrodes were essentially straight lines, while those for stainless steel were elliptical 


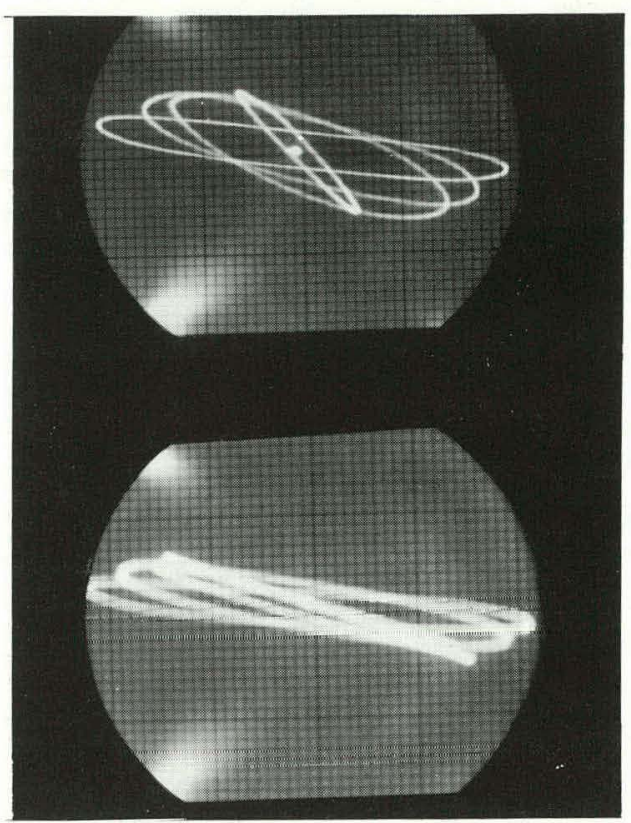

Platinum Electrode $-0.2 \mathrm{~cm}^{2}$

Horizontal -0.02 v per division Vertical $-10^{-4}$ amperes per division

Frequency $10^{2}, 10^{3}, 10^{4}, 10^{5} \mathrm{cps}$

Slope of major axis increases with frequency

Platinized Platinum $-0.06 \mathrm{~cm}^{2}$

Horizontal -0.02 v per division

Vertical $-10^{-3}$ amperes per division

Frequency $10^{2}, 10^{3}, 10^{4}, 10^{5} \mathrm{cps}$

Slope of major axis increases with frequency

Tantalum Electrode $-1.0 \mathrm{~cm}^{2}$

Horizontal -0.02 v per division

Vertical - $10^{-4}$ amperes per division

Frequency $10^{2}, 10^{3}, 10^{4}, 10^{5} \mathrm{cps}$

Slope of major axis increases with frequency

Stainless Steel Electrode $-0.7 \mathrm{~cm}^{2}$ Horizontal -0.2 v per division Vertical $-10^{-4}$ amperes per division Frequency $10^{2}, 10^{3}, 10^{4}, 10^{5} \mathrm{cps}$ Slope of major axis increases with frequency

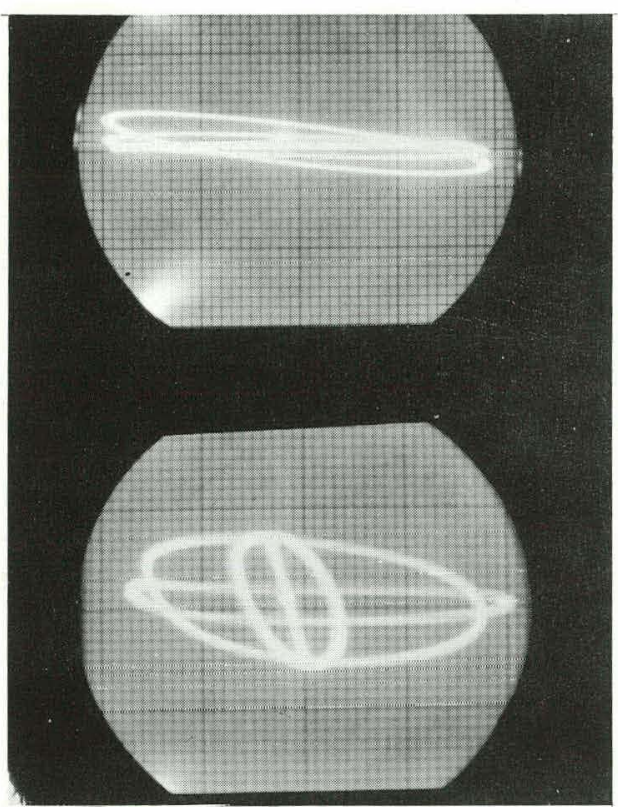

FIG. 7 CYCLOGRAMS OF $0.14 \mathrm{M} U \mathrm{UNH}-0.2 \mathrm{M} \mathrm{HNO}$ 
traces. Platinum was intermediate between these two. The phase angle decreased with frequency for all electrodes. Tantalum electrodes exhibited high polarization resistance and small capacity at all frequencies.

The above results indicate that stainless steel electrodes can be utilized in conductivity cells, while tantalum should not be used due to the high polarization resistance.

\section{WATER - INSOLUBLE ORGANIC SOLVENTS}

Since Purex plant streams contain dissolved and suspended organic solvent that is nearly insoluble in water, the effect on the response of conductivity cells of coating the electrodes with solvent was studied for three different cell designs: a commercial dip-type cell with $1-\mathrm{cm}^{2}$ disc electrodes spaced $3 \mathrm{~cm}$ apart and centered inside a $2.8-\mathrm{cm}$ cylindrical glass sleeve, and the two designs shown in Figures $3 \mathrm{~b}$ and $3 \mathrm{c}$. The commercial dip-lype vell was los luded for einjarative purpozes. Cell response was determined with the equipment shown in Figure 2.

The cells were cleaned with acid-dichromate cleaning solution and rinsed with distilled water prior to use. The electrodes were not platinized. The specific resistance $(\bar{R})$ of the test solution ( $0.14 \mathrm{M}$ uranyl nitrate $-0.2 \mathrm{M}$ nitric acid) was determined by the elestrode separation technique in a cell of the design shown in Figure $3 b$. This value of $\bar{R}$ was used to determine the cell constants for the dip-type and flow cells. After the initial impedance measurements were made, the cells were flooded with solvent, rinsed three times with distilled water, once with the test solution, and finally filled with fresh test solution. The impedance of the test solution was then remeasured. In the case of the flow cell, the organic solvent was simply flushed from the cell with fresh test solution. The results are given in Table VI. Although the

\section{TABLE VI}

Effect of Organic Solvents on Cell Response

Test solution: $0.14 \mathrm{M} \mathrm{UO}_{2}\left(\mathrm{NO}_{3}\right)_{2}-0.2 \mathrm{M} \mathrm{HNO}{ }_{3}, f=10^{5} \mathrm{cps}$

\begin{tabular}{|c|c|c|c|}
\hline \multirow[b]{2}{*}{ Vel1 'l'reatment } & \multicolumn{3}{|c|}{$\bar{R}$, ohm-oentimeter } \\
\hline & Lip Type & $\begin{array}{l}A=1.224 \mathrm{~cm}^{2} \\
(\text { F1gure } 3 \mathrm{~b})\end{array}$ & $\begin{array}{l}A=0.16 \mathrm{~cm}^{2} \\
\text { (F1gure } 3 \mathrm{c})\end{array}$ \\
\hline Clean cell & $11.76^{(a)}$ & 11.76 & $.11 .76^{(a)}$ \\
\hline $\begin{array}{l}\text { Flood with } \\
30 / 70 \mathrm{TBP}\end{array}$ & $16.35^{(b)}$ & $11.76^{(b)}$ & 11.76 \\
\hline $\begin{array}{l}\text { Flood w1 th } \\
\text { SAE } 30 \text { oil }\end{array}$ & $21.48^{(b)}$ & $11.87^{(b)}$ & 11.76 \\
\hline $\begin{array}{l}\text { Clean cell } \\
\text { w1 th detergent. }\end{array}$ & 12.28 & - & - \\
\hline $\begin{array}{l}\text { (a) Corrected f } \\
\text { by electrod } \\
\text { (b) Flooded wit } \\
\text { once w1 th } \\
\text { rcdetermine }\end{array}$ & $\begin{array}{l}\text { geometry } \\
\text { separatio } \\
\text { solvent, } \\
\text { t solutio } \\
\bar{R} \text {. }\end{array}$ & $\begin{array}{l}\text { based on value } \\
\text { method. } \\
\text { rinsed three tin } \\
\text {; refilled test }\end{array}$ & $\begin{array}{l}\text { f } \bar{R} \text { obtalned } \\
\text { s wlth water, } \\
\text { solution and }\end{array}$ \\
\hline
\end{tabular}


SAE 30 motor oil will not normally be found in organic streams, such a condition might arlse from a broken pump seal and was included to indicate the worst conditions.

The results indicate that the commercial dip-type cell would be unsatisfactory in this service, even if the cell could be flushed periodically with a detergent solution. The response of the long path cells returned to within $1 \%$ of the initial readings; however, the flow cell was superior in this regard due to a more favorable geometry. The coating of the electrodes with organic solvent will have a minimum effect on the response of a properly designed cell.

The flow cell was tested for sensitivity to flow in the range of 0 to 600 milliliters per minute. No sensitivity to t'low rate was detected.

\section{BRIDGE AND CONSTANT CURRENT METHODS}

Examination of the results for $R_{m}$ and $Z_{m}$ obtained during this study (Table I) shows that at frequencies of $10^{3}, 10^{4}$, and $10^{5} \mathrm{cps}$ the results were related by a proportionality constant. The slopes of the lines representing the ratios were as follows:

$\begin{array}{llll}\text { Frequency, cps } & 10^{3} & 10^{4} & 10^{5} \\ \mathrm{R}_{\mathrm{m}} / \mathrm{Z} & 1.12 & 1.06 & 1.05\end{array}$

The results show that the ratio decreased as the frequency was increased. The differences in $R_{m}$ and $z$ are due to the effects of $C_{Q}$ and $C_{S}$ as explained previously.

\section{ABSOLUTE NATURE OF THE ELECTRODE SEPARATION METHOD}

The absolute nature of the electrode separation method for the measurement of the specific resistance of solutions is evidenced in the work of Miller(s), Jones( ${ }^{(2)}$, and Remick(8). Jones and hemick were primarily interested in the ef'fects of electrode polarization phenomena, and utilized the method of' Miller to determine both the specific resistance of the solution $(\bar{R})$ and the effective polarization resistance $\left(R_{S}\right)$. Both workers report that the measured values for $\bar{R}$ were in agreement with those obtained by the classical Kohlrausch method and also noted the frequency independence of this term in the Milier equation. However, neither Jones nor Remick claimed the prodedure as a method for the determination of the absolute value of $\bar{R}$, perhaps because Jones proposed to correct conductivity results by extrapolating plots of $R_{m}$ vs $f^{-\frac{1}{2}}$ to zero frequency. However, Remick $(9)$ has shown that plots of $R_{m}$ vs $I$ 
extrapolated to zero distance give answers in better agreement with the Kohlrausch method.

Since the value for $\bar{R}$ as determined by the electrode separation technique is independent of $R_{S}$, whereas $R_{S}$ is included in the results obtalned by the Kohlrausch method, the electrode separation technique should provide a basis for the measurement of absolute values for $\bar{R}$.

The validity of the modified Miller equation for the measurement of $\bar{R}$ is illustrated by the results obtained for the effect of the cross-sectional area of the solution (see page 13).

The standard $0.1000 \mathrm{~N}$ potassium chloride solution used in these experiments was prepared from the salt that had been previously dried to constant weight at $105^{\circ} \mathrm{C}$. The literature value $(10)$ for the specific resistance of this solution was $77.83 \mathrm{ohm}$-centimeters at $25^{\circ} \mathrm{C}$, whlch extrapolates to $78.15 \mathrm{ohm}-$ centimeters at $24.8^{\circ} \mathrm{C}$, the temperature of the test solution.

The average result of $78.6 \pm 0.5 \mathrm{ohm}$-centimeters agrees with the extrapolated literature value of 78.15 ohm-centimeters within the limits of error of the experimental procedure. Thus the modified Miller equation 1 s valid for the determination of $\bar{R}$ by the electrode separation method.

In view of the relative precision of the experimental techniques utilized in this study, further experiments of a more precise nature will be conducted in the near future to substantiate further the above results. However, the validity of the original Miller equation is demonstrated in the work of Jones $^{(2)}$, and 1t was the sole purpose of this section to demonstrate the validity of the modified equation of Miller as applied to in-line measurements at the $1 \%$ level.

\section{APPLICATION TO THE URANYL NITRATE - NITRIC ACID SYSTEM}

Conductivity and specific gravity are critical indices of the composition of the uranyl nitrate - nitric acid system, and provide a means for the continuous analysis of raw metal feed solutions. A typical graph of conductivity versus specific gravity for solutions of various uranyl nitrate - nitric acid compositions is given in Figure 8 .

The analysis of raw metal feed solutions with an accuracy of $1 \%$ requires a corresponding accuracy in conductivity and specific gravity determinations. This requirement is within the scope of conductivity measurements; however, the current differential pressure technique for measuring specific gravity 


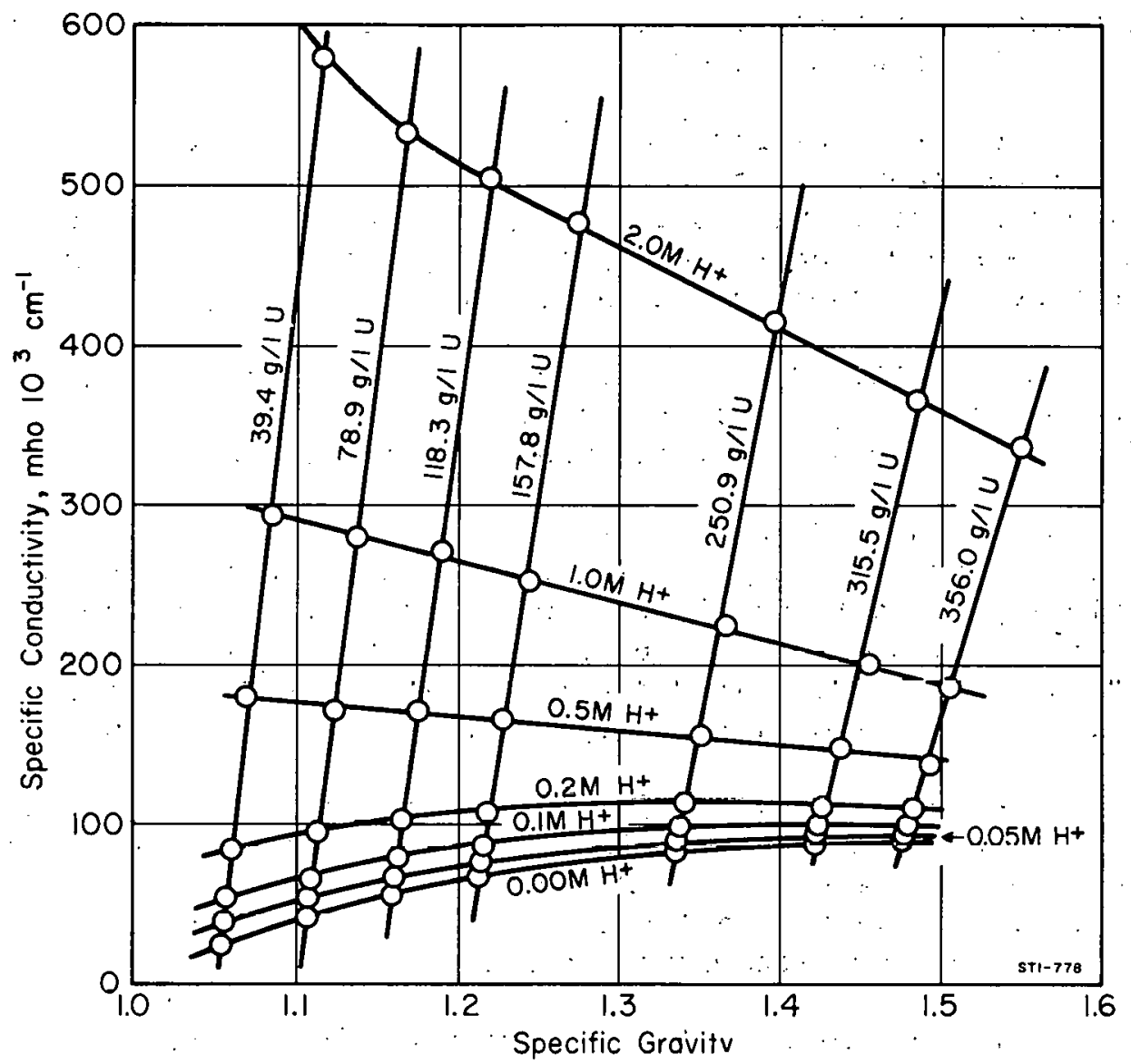

FIG. 8 SPECIFIC GRAVITY VS CONDUCTIVITY, UO ${ }_{2}\left(\mathrm{NO}_{3}\right)_{2}-\mathrm{HNO}_{3}$ SYSTEM

In the Plant is sensitive to 0.01 specific gravity units when the distance between air bubble pipes is 10 1nches. This. corresponds to a $0.03 \mathrm{M}$ change in uranyl nitrate concentration. In order to obtain a sensitivity of $1 \%$, the pressure differential will have to be increased to 30 inches $\mathrm{H}_{2} \mathrm{O}$, or another more sensitive method is needed. 


\section{REFERENCES}

1. Green, R. M. "Electrical Measurement as Applied to a Continuous Analysis". Inst. Soc. Am., Proc. 14, Paper No. 130 (1959).

2. Jones, G. and S. M. Christian. "The Measurement of the Conductance of Electrolytes. VI. Galvanic Polarization by Alternating Current". J.Am. Chem. Soc. 57, 272-80 (1935).

3. Grahame, D. C. "Mathematical Theory of the Faradaic Admittance." J. Electrochem. Soc. 99, 370C-85C (1952).

4. Delahay, P. New Instrumental Methods in Electrochemistry. pp. 146-78, New York: Interscience Publishers, Inc. (1954).

5. Randles, J. E. B. "Kinetics of Rapid Electrode Reactions". Discussions Faraday Soc. 1, 11 (1947).

6. Potter, E. C. Electrochemistry, p. 130, London: CleaverHume Press, Ltd. (1956).

7. Silverman, J. and A. E. Remick. "Studies on Alternating Current Electrolysis. II. Oscillographic studies". J. Electrochem. Soc. 97, 335-45 (1950).

8. Miller, C. W. "A Direct Measurement of Polarization Capacity and Phase Angle". Phys. Rev. 22, 622-28 (1923).

9. Remick, A. E. and H. W. McCormick. "Studies on AlternatingCurrent Electrolysis. III. Effects of Concentration on Polarization capacity and Polarization Resistance". J. Electrochem. Soc. 102, 534-44 (1955).

10. Gunnting, H. E. and A. R. Gordon. "The Conductance and Ionic Mobilities for Aqueous Solutions of Potassium and Sodium Chloride at Temperatures from $15^{\circ}$ to $45^{\circ} \mathrm{C}$. J. Chem. Phys. 10, 126-31 (1942). 